Portland State University

PDXScholar

\title{
Modeling Regional Secondary Organic Aerosol Using the Master Chemical Mechanism
}

Jingyi Li

Texas A\&M University

Meredith Cleveland

SRA International

Luke D. Ziemba

NASA Langley Research Center

Robert J. Griffin

Rice University

Kelley Barsanti

Portland State University, barsanti@pdx.edu

See next page for additional authors

Follow this and additional works at: https://pdxscholar.library.pdx.edu/cengin_fac

Part of the Civil Engineering Commons, and the Environmental Engineering Commons Let us know how access to this document benefits you.

\section{Citation Details}

Jingyi Li, Meredith Cleveland, Luke D. Ziemba, Robert J. Griffin, Kelley C. Barsanti, James F. Pankow, Qi Ying, Modeling regional secondary organic aerosol using the Master Chemical Mechanism, Atmospheric Environment, Volume 102, February 2015, Pages 52-61.

This Article is brought to you for free and open access. It has been accepted for inclusion in Civil and Environmental Engineering Faculty Publications and Presentations by an authorized administrator of PDXScholar. Please contact us if we can make this document more accessible: pdxscholar@pdx.edu. 


\section{Authors}

Jingyi Li, Meredith Cleveland, Luke D. Ziemba, Robert J. Griffin, Kelley Barsanti, James F. Pankow, and Qi Ying 


\title{
Modeling regional secondary organic aerosol using the Master Chemical Mechanism
}

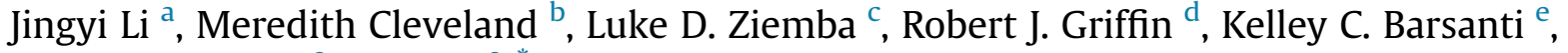 \\ James F. Pankow ${ }^{\mathrm{e}}$, Qi Ying ${ }^{\text {a, * }}$ \\ a Zachry Department of Civil Engineering, Texas A\&M University, College Station, TX 77843, USA \\ b SRA International, Washington, DC 20005, USA \\ ${ }^{c}$ NASA Langley Research Center, Hampton, VA 23681, USA \\ d Department of Civil and Environmental Engineering, Rice University, Houston, TX 77005, USA \\ e Department of Civil and Environmental Engineering, Portland State University, OR 97021, USA
}

\section{H I G H L I G H T S}

- First application of a near-explicit chemical mechanism in 3D CTM for SOA predictions.

- Predicted SOA mass and O/C and N/C generally agree with AMS data in urban Houston.

- Semi-volatile SOA products (mostly from $\beta$-caryophyllene) account for $20 \%$ of SOA.

- Predicted semi-volatile SOA mass is sensitive to estimated saturation vapor pressure.

- Dicarbonyls and isoprene epoxydiols contribute significantly to modeled SOA.

\section{A R T I C L E I N F O}

\section{Article history:}

Received 20 August 2014

Received in revised form

22 November 2014

Accepted 24 November 2014

Available online 24 November 2014

\section{Keywords:}

MCMv3.2

CMAQ model

Isoprene epoxydiol

Glyoxal

Surface reactive uptake

\begin{abstract}
A B S T R A C T
A modified near-explicit Master Chemical Mechanism (MCM, version 3.2) with 5727 species and 16,930 reactions and an equilibrium partitioning module was incorporated into the Community Air Quality Model (CMAQ) to predict the regional concentrations of secondary organic aerosol (SOA) from volatile organic compounds (VOCs) in the eastern United States (US). In addition to the semi-volatile SOA from equilibrium partitioning, reactive surface uptake processes were used to simulate SOA formation due to isoprene epoxydiol, glyoxal and methylglyoxal. The CMAQ-MCM-SOA model was applied to simulate SOA formation during a two-week episode from August 28 to September 7, 2006. The southeastern US has the highest SOA, with a maximum episode-averaged concentration of $\sim 12 \mu \mathrm{g} \mathrm{m}^{-3}$. Primary organic aerosol (POA) and SOA concentrations predicted by CMAQ-MCM-SOA agree well with AMS-derived hydrocarbon-like organic aerosol (HOA) and oxygenated organic aerosol (OOA) urban concentrations at the Moody Tower at the University of Houston. Predicted molecular properties of SOA (O/C, H/C, N/C and OM/ $O C$ ratios) at the site are similar to those reported in other urban areas, and $O / C$ values agree with measured $\mathrm{O} / \mathrm{C}$ at the same site. Isoprene epoxydiol is predicted to be the largest contributor to total SOA concentration in the southeast US, followed by methylglyoxal and glyoxal. The semi-volatile SOA components are dominated by products from $\beta$-caryophyllene oxidation, but the major species and their concentrations are sensitive to errors in saturation vapor pressure estimation. A uniform decrease of saturation vapor pressure by a factor of 100 for all condensable compounds can lead to a $150 \%$ increase in total SOA. A sensitivity simulation with UNIFAC-calculated activity coefficients (ignoring phase separation and water molecule partitioning into the organic phase) led to a $10 \%$ change in the predicted semivolatile SOA concentrations.
\end{abstract}

(c) 2014 Elsevier Ltd. All rights reserved.

\footnotetext{
* Corresponding author.

E-mail address: qying@civil.tamu.edu (Q. Ying).
}

\section{Introduction}

Organic aerosol is a major component of airborne particulate matter that affects human health and global climate. A significant 
fraction of ambient organic aerosol is often secondary in origin, formed in the atmosphere by gas-to-particle conversion of reaction products of volatile organic compounds (VOCs) emitted from anthropogenic and biogenic sources (Kroll and Seinfeld, 2008). Traditionally, predictions of secondary organic aerosol (SOA) in atmospheric chemical transport models (CTMs) are mostly based on equilibrium absorption partition theory (Pankow, 1994), often using parameters from two-product (Odum et al., 1996) fits to laboratory chamber data for SOA yields for a limited number of precursor organic compounds. Lumped or representative species have been used to represent many precursor VOCs and their oxidation products in CTMs (Pandis et al., 1993). That type of SOA modeling approach has been implemented in many widely-used regional and global CTMs such as the Community Multi-scale Air Quality (CMAQ) model (Carlton et al., 2010) and the GEOS-CHEM model (Liao et al., 2007).

Although the two-product equilibrium partitioning method can generally reproduce well-controlled laboratory measurements at relatively high SOA levels, simulated SOA concentrations have been universally lower than measured field concentrations (Heald et al., 2005). The under-prediction has been attributed partially to the fact that the two-product method does not consider photochemical aging of gas precursors or multi-generation formation of SOA products. The volatility basis set (VBS) approach addresses this problem by assuming time dependence of the VBS for the organic compounds (Robinson et al., 2007). Like the two-product model, however, the VBS approach does not attempt to model detailed products, and the initial volatility distribution of the emissions and products as well as the time-dependence of the VBS due to aging need to be fit from measurements, or guessed. In addition, there are also growing laboratory and field evidence that secondary organic aerosol components are in an amorphous solid state and thus are not in equilibrium with their gas phase semi-volatile precursors (Virtanen et al., 2010). Current SOA models may have over predicted the evaporation rate and thus lead to under-predictions of SOA (Vaden et al., 2011).

In parallel with the continued devolvement of lumped approaches in SOA modeling in CTMs, progress has been made in treating individual important SOA precursors and their oxidation products with greater detail as based on new experimental evidence. For example, SOA formation from gas-phase precursors such as dicarbonyls has been included in recent versions of many CTMs (Fu et al., 2008; Volkamer et al., 2007). More recently, isoprene epoxydiols have been found to be important SOA precursors (Lin et al., 2012b), and their potential contributions to global SOA have been studied using a three-dimensional (3D) global CTM (Lin et al., 2012a). Modeling these species usually requires additional modification of existing gas phase mechanisms and to consider reactive surface uptake (Ervens and Volkamer, 2010).

Another important development in SOA modeling is the use of explicit VOC oxidation mechanisms to represent multistage oxidation. In particular, the physical properties of particular or representative organic model species, such as the saturation vapor pressure $\left(p_{L}^{o}\right)$, can be estimated based on experimental data or molecular structure, allowing explicit calculation of SOA formation. Early computationally limited attempts of this type sought to predict regional SOA using a small number of representative precursor and product species (Griffin et al., 2002b). More recently, nearexplicit photochemical mechanisms that simulate the formation of individual semi-volatile products from a large number of explicit precursor species have been developed. For example, Madronich and co-workers developed a very detailed near-explicit photochemical mechanism for SOA simulation (Camredon et al., 2007) and applied that in a chemical box model to study SOA formation in Mexico City (Lee-Taylor et al., 2011). Another example of a near- explicit chemical mechanism is the Master Chemical Mechanism (MCM), which uses $\sim 6000$ explicit species and $\sim 15,000$ reactions to represent the multi-step reaction of a large number of primary emitted VOCs in the troposphere (Bloss et al., 2005; Jenkin et al., 1997, 2003). Verification and evaluation of SOA simulations using MCM have been carried out for a number of VOC precursors in box models (Jenkin, 2004; Johnson et al., 2004, 2005). MCM also has been implemented in Lagrangian models to study the formation of SOA under ambient conditions (Johnson et al., 2006a). Implementation of MCM in a more general 3D Eulerian modeling framework has not been attempted until recently (Ying and $\mathrm{Li}$, 2011), and no regional SOA calculation using MCM in a 3D CTM has been reported.

In this study, we describe the formulation of an SOA module and its implementation in the CMAQ-MCM model previously developed by Li et al. (2013), and the application of the model (termed CMAQMCM-SOA hereafter) to study regional SOA in the eastern US during a two-week summer episode in 2006. This is the first time a nearexplicit photochemical mechanism was applied in a regional 3D CTM to simulate SOA formation. Major first and later-generation volatile organic compounds (VOCs) species that form SOA are identified. In addition, contributions to SOA concentrations due to surface uptake of isoprene epoxydiols and dicarbonyls are determined. Model sensitivities due to uncertainties in $p_{L}^{0}$ and activity coefficient in the mixed organic phase $(\xi)$ are discussed.

\section{Model description}

The CMAQ-MCM model described in Ying and Li (2011) does not treat aerosol processes. Li et al. (2013) expanded the CMAQ-MCM to treat inorganic aerosol species using the aerosol module version 5 (AERO5) in CMAQ. In this study, an organic aerosol module was implemented in CMAQ-MCM to simulate SOA formation from the equilibrium partitioning of semi-volatile precursors and from reactive surface uptake of isoprene epoxydiol and dicarbonyls (glyoxal and methylglyoxal). An overview of the CMAQ-MCM-SOA model, including a summary of the MCM v3.2 gas phase mechanism (Bloss et al., 2005; Jenkin et al., 2003, 2012; Saunders et al., 2003), the host CMAQ model (Byun and Schere, 2006; Foley et al., 2010) and the aerosol processes is included in the Supplementary Material. In the following, treatment of SOA formation from equilibrium partitioning and reactive surface uptake processes is discussed in greater detail.

\subsection{SOA formation from equilibrium partitioning of SVOCS}

The partitioning of an individual SVOC in CMAQ-MCM-SOA is assumed to follow the equilibrium absorption-partitioning theory of Pankow (1994), as described in Equation (1),

$\frac{M_{\mathrm{org}, i}}{M_{\mathrm{air}, i}}=\frac{R T}{10^{6} \overline{\mathrm{MW}}_{\mathrm{om}} \zeta_{\mathrm{org}, i} p_{L, i}^{\mathrm{o}}} M_{\mathrm{om}}$

where $M_{\mathrm{air}}$ and $M_{\mathrm{org}}$ are mass concentrations $\left(\mu \mathrm{g} \mathrm{m}^{-3}\right.$ ) of the partitioning SVOC, $\zeta_{\text {org }, i}$ is the activity coefficient of $i$ in the organic aerosol matrix, and $\overline{\mathrm{MW}}_{\mathrm{om}}$ and $M_{\mathrm{om}}$ are the average molecular weight $\left(\mathrm{g} \mathrm{mol}^{-1}\right)$ and the mass concentration of the absorbing organic phase $\left(\mu \mathrm{g} \mathrm{m} \mathrm{m}^{-3}\right) . R$ is the universal gas constant $\left(8.314 \mathrm{~J} \mathrm{~mol}^{-1} \mathrm{~K}^{-1}\right), T$ is ambient temperature $(\mathrm{K})$, and $10^{6}$ converts $\mathrm{g}$ to $\mu \mathrm{g}$. Equation (1) can be rewritten as:

$M_{\mathrm{org}, i}=M_{\mathrm{air}, i} \frac{C_{\mathrm{om}}}{\zeta_{\mathrm{org}, i} C_{\mathrm{org}, i}^{*}}$ 
where $C_{o m}$ is the molar concentration of the total aerosol organic matter $\left(\mu \mathrm{mol} \mathrm{m}{ }^{-3}\right)$ and $C_{\text {org }}^{*}$ is saturation concentration $\left(\mu \mathrm{mol} \mathrm{m}{ }^{-3}\right)$ with

$$
C_{\mathrm{om}}=\frac{M_{\mathrm{om}}}{\overline{\mathrm{MW}}_{\mathrm{om}}}
$$

$C_{\mathrm{org}, i}^{*}=\frac{10^{6} p_{L, i}^{\mathrm{o}}}{R T}$

In CMAQ-MCM-SOA, $C_{\text {om }}$ is calculated based on the concentrations of primary organic aerosol (POA), semi-volatile SOA, and nonvolatile accretion products from semi-volatile SOA components:

$$
\begin{aligned}
C_{\mathrm{om}}= & \sum_{i=1}^{N_{\mathrm{POA}}}\left(M_{\mathrm{POA}, i} / \mathrm{MW}_{\mathrm{POA}, i}\right)+\sum_{i=1}^{N_{\mathrm{SOA}}}\left(M_{\mathrm{org}, i} / \mathrm{MW}_{\mathrm{Org}, i}\right) \\
& +\sum_{i=1}^{N_{\mathrm{nvol}}}\left(M_{\mathrm{nvol}, i} / \mathrm{MW}_{\mathrm{nvol}, i}\right)
\end{aligned}
$$

where $M_{\mathrm{POA}}$ and $M_{\mathrm{nvol}}$ are mass concentrations of primary and nonvolatile organic aerosol components, respectively. $\mathrm{MW}_{\mathrm{POA}}, \mathrm{MW}_{\mathrm{Org}}$ and $\mathrm{MW}_{\mathrm{nvol}}$ are the molecular weights of primary, secondary volatile, and secondary non-volatile organic aerosol components, respectively. Based on mass conservation, the mass concentration of an SVOC in the gas and organic phase can be determined using the total concentration $\left(M_{\text {tot,i }}\right)$ using Equations (5) and (6),

$M_{\mathrm{air}, i}=M_{\mathrm{tot}, i}\left(1+\frac{C_{\mathrm{om}}}{\zeta_{\mathrm{org}, i} C_{\mathrm{org}, i}^{*}}\right)^{-1}$

$M_{\mathrm{org}, i}=M_{\mathrm{tot}, i}-M_{\mathrm{air}, i}$

Equations (5)-(7) are used to solve the equilibrium partitioning of SVOCs between the gas and organic phases. While many SOA modeling studies using detailed gas-phase mechanisms only allow a relatively small number of lumped products to partition into the organic phase as based on some selection criteria (Lin et al., 2012a), here all 3414 non-radical organic species produced in the gas-phase MCM are allowed to condense. Note that the term 'SVOC' is being used very broadly here to refer to any compound $i$ with non-zero vapor pressure.

An iteration method (Jacobson et al., 1996) originally used to solve systems of chemical equilibrium reactions was applied to solve iteratively the phase partitioning equilibrium of a large number of species. Briefly, the method requires the solution of the phase partitioning equilibrium, as described by Equations (6) and (7), for one species at time. The partitioning system was solved by iterating all species several times until the concentrations of the species in the om phase and the total concentration $C_{o m}$ no longer changed. Convergence for each species was examined based on a combination of absolute and relative error (Jacobson, 1998):

$E_{i}^{n}=\frac{M_{\mathrm{org}, i}^{n}-M_{\mathrm{org}, i}^{n-1}}{R_{\mathrm{tol}} M_{\mathrm{org}, i}^{n-1}+A_{\mathrm{tol}}}$

where $E_{n}^{i}$ is the error for $i$ th species during the $n$th iteration, $R_{\text {tol }}$ is the relative error tolerance and $A_{\text {tol }}$ is the absolute error tolerance. For regional simulations using CMAQ-MCM-SOA, the $R_{\text {tol }}$ and $A_{\text {tol }}$ values were set to 0.01 and $1 \times 10^{-4} \mu \mathrm{g} \mathrm{m}^{-3}$, respectively. Convergence was accepted once all $E_{i}<0.1$.

$p_{L}^{o}$ values (sub-cooled if necessary) for Equation (4) were estimated using the MPBPVP program, which uses the Modified Grain
Method as described by Lyman (Lyman, 1985) and used in the EPI package developed by US EPA (USEPA, 2009) (http://www.epa.gov/ oppt/exposure/pubs/episuitedl.htm). The EPI package has been used in previous modeling applications to estimate SVP (e.g. Na et al., 2006) and has been extensively compared with other methods (McFiggans et al., 2010; Schnitzler and McDonald, 2012). Temperature dependence of SVP values was included in CMAQMCM-SOA using EPI-predicted SVPs at different temperatures followed by fitting to obtain parameters $A$ and $B$ in (Jacobson, 1999); $T_{0}=298.15 \mathrm{~K}$ :

$p_{L, i}^{\mathrm{o}}(T)=p_{L, i}^{\mathrm{o}}\left(T_{0}\right) \exp \left[A_{i}\left(\frac{1}{T_{0}}-\frac{1}{T}\right)+B_{i} \ln \frac{T_{0}}{T}\right]$

The activity coefficients of the condensed SVOCs in the organic phase were calculated using the UNIversal Functional Activity Coefficient (UNIFAC) method (Fredenslund et al., 1975). The UNIFAC method implemented in the current model uses the structural groups and energy interaction parameters as collected in the Extended AIM Aerosol Thermodynamics Model (Clegg et al., 2008) (available at http://www.aim.env.uea.ac.uk/aim/info/ UNIFACgroups.html). A structure fragmentation program (Ihlenfeldt, personal communication) was used to determine the UNIFAC structures for the SVOCs based on their Simplified Molecular-Input Line-Entry System (SMILE) strings. A number of species, however, contained groups that cannot be represented the current version of UNIFAC. The nitrate (ONO2) group was replaced with $\mathrm{CHNO} 2$ (Chang and Pankow, 2010), and manual adjustments were applied as needed if a simple move of a $-\mathrm{CH}_{3},-\mathrm{OOH}$ or other functional group allowed resolution of a structure. Overall, UNIFAC structures for 2105 species were resolved, and the species included in the activity coefficient calculations. Species with assigned structures accounted for $88-96 \%$ of the total predicted semi-volatile SOA mass. In the base-case simulation described below, UNIFAC was not enabled, and all activity coefficients were taken as unity; sensitivity in the predicted SOA concentrations due to inclusion of UNIFAC activity calculation is discussed in Section 3.3.2.

As the current model assumes a single organic mixture phase, composition of POA also needs to be assigned. In CMAQ-MCM-SOA, POA emissions are classified into eight categories: $n$-alkanes (represented by the surrogate species $n$-nonacosane), polycyclic aromatic hydrocarbons (PAH) (as benzo(ghi)-perylene), oxygenated PAH (as 2,6-naphthalene-diacid), aliphatic monoprotic acids (as octadecanoic acid), aliphatic diacids (as butanedioic acid), substituted monoaromatic compounds (as phthalic acid), cyclic petroleum biomarkers (as $17(\alpha) \mathrm{H}-21(\beta) \mathrm{H}$-hopane), and unresolved organic matter (as a highly cyclic, saturated, and branched petroleum biomarker) (Griffin et al., 2002a). More details of the structures and properties of the surrogate species can be found in Table 5b of Pun et al. (2002). In this study, it is assumed that these species are non-volatile and equally contribute to the predicted POA concentrations. Molecular weights of these species are used in Equation (5) to calculate molar concentrations of POA. A more realistic simulation of speciated POA emissions and their aging in the atmosphere is needed in future studies.

\subsection{Uptake of isoprene epoxydiol, glyoxal and methylglyoxal}

In addition to reversible equilibrium partitioning of SVOCs, formation of non-volatile SOA from isoprene epoxydiol under low$\mathrm{NO}_{x}$ conditions (Paulot et al., 2009) and from glyoxal and methylglyoxal (Ervens and Volkamer, 2010; Volkamer et al., 2007) were assumed to undergo surface-controlled irreversible uptake according to 
$\frac{\mathrm{d} M_{\mathrm{air}, i}}{\mathrm{~d} t}=-\left(\frac{1}{4} \gamma_{i} v_{i} A\right) M_{\mathrm{air}, i}$

where $A$ is the aerosol surface area concentration $\left(\mathrm{m}^{2} \mathrm{~m}^{-3}\right), \gamma$ is the reactive uptake coefficient, $v$ is the thermal velocity of the gas molecule $\left(\mathrm{m} \mathrm{s}^{-1}\right)$. Molecular formula of SOA products from these such reactions are not known, so the molecular weights of the precursors (118.1 $\mathrm{g} \mathrm{mol}^{-1}$ for isoprene epoxydiol, $58.04 \mathrm{~g} \mathrm{~mol}^{-1}$ for glyoxal and $72.06 \mathrm{~g} \mathrm{~mol}^{-1}$ for methylglyoxal) were retained for the respective products for use in Equation (5). It is assumed here that aerosols have an aqueous shell surrounding a core that is made up of carbonaceous and insoluble inorganic materials so uptake process occurs on the entire particle surface. This provides an upper limit estimation of the importance of surface uptake, if part of the aerosol surface is not covered with an aqueous layer.

Daytime irreversible uptake of glyoxal was modeled using Equation (10) with $\gamma_{\text {glyoxal }}=2.9 \times 10^{-3}$ (Fu et al., 2008; Lin et al., 2012a). The nighttime irreversible uptake was modeled with a surface-area independent rate coefficient of $3.33 \times 10^{-4} \mathrm{~s}^{-1}$ (Ervens and Volkamer, 2010). SOA formation from methylglyoxal was modeled with glyoxal. The approach here follows that of (Ying et al., 2014) for use in a modified CMAQ model using the SAPRC-99 photochemical mechanism to study SOA formation in Mexico City. Although MCM also includes other dicarbonyl compounds which can potentially contribute to SOA formation, they were not considered in this study due to their low concentrations.

Values of the uptake coefficient of isoprene epoxide ( $\left.\gamma_{\text {epoxide }}\right)$ on acid particles have been reported in several previous studies. As no direct measurements of the uptake coefficient of isoprene epoxidiol ( $\left.\gamma_{\text {IEPOX }}\right)$ have been reported, $\gamma_{\text {epoxide }}$ was used in this study as an estimation of $\gamma_{\text {IEPOX. }}$. Lal et al. (2012) measured $\gamma_{\text {epoxide }}=1.71 \times 10^{-2}$ using $90 \% \mathrm{H}_{2} \mathrm{SO}_{4}$ solution. Wang et al. (2012) measured $\gamma_{\text {epoxide }}$ using $\mathrm{H}_{2} \mathrm{SO}_{4}$ solution at different acidity levels, up to $20 \% \mathrm{H}_{2} \mathrm{SO}_{4}$ by weight. Fig. 1 shows $\gamma_{\text {epoxide }}$ as a function of hydrogen ion molality $\left(m_{\mathrm{H}^{+}}\right)$reported by these two studies. A second-order polynomial was used to fit the dependence of $\gamma_{\text {epoxide }}$ on $m_{\mathrm{H}^{+}}$according to:

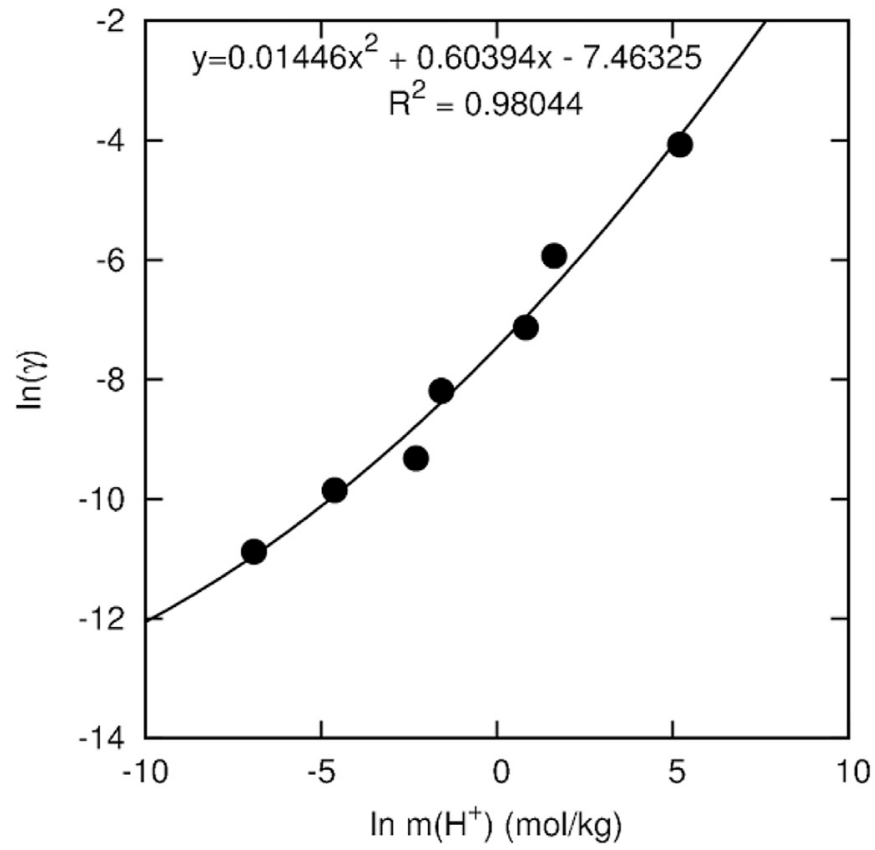

Fig. 1. Relationship between molality of hydrogen ion and uptake coefficient of isoprene epoxide.

$$
\ln \gamma_{\text {epoxide }}=0.01446\left(\ln m_{\mathrm{H}^{+}}\right)^{2}+0.60394 \ln m_{\mathrm{H}^{+}}-7.46325
$$

Values of $m_{\mathrm{H}^{+}}$were predicted using the thermodynamic equilibrium model ISORROPIA (Nenes et al., 1998).

\section{Results}

\subsection{Model performance evaluation}

Model performance of ozone was examined first, as ozone directly affects SOA formation and is a good metric for successful gas-phase mechanism behavior. Diurnal variation of ozone concentrations in several urban, rural, and suburban areas are shown in Fig. S2. CMAQ-MCM-SOA successfully captured the diurnal and day-to-day patterns. Overall model performance statistics for $1 \mathrm{~h}$ and $8 \mathrm{~h}$ ozone using data at all stations are given in Table S1.

Fig. S3 compares predicted and observed daily $\mathrm{PM}_{2.5}$ organic carbon $(\mathrm{OC})$ concentrations for two days. The predicted concentrations are in general spatial agreement with most of the observed values. However, the model performance statistics (Fig. S4(a)) indicate that $\mathrm{OC}$ concentrations at the monitoring sites were underpredicted. As elemental carbon (EC) is under-predicted (Fig. S4(b)), it is possible that POA is also under-predicted as they are often coemitted from transportation and combustion sources. The agreement would be better if concentrations of POA at these sites were captured well by the model.

Fig. 2 shows the comparison of predicted POA and SOA with hydrocarbon-like organic aerosol (HOA) and oxidized organic aerosol (OOA) measured by an Aerosol Mass Spectrometer (AMS) on top of the Moody Tower at the University of Houston during the Radical and Aerosol Measurement Project (TRAMP) (Cleveland et al., 2012). Predicted POA generally agrees with the temporal variation of AMS HOA and reproduces the observed morning and evening traffic peaks. Predicted SOA agrees with the AMS OOA values on most of the days, especially on September 1 and 3. Mean fractional bias (the average of the fractional bias for all points; see SI for the definition of fractional bias) values for hourly POA and SOA concentrations over the entire episode were 0.18 and -0.01 , respectively. The OOA/HOA ratios were also reproduced well, if assuming OOA and HOA can be represented by SOA and POA, respectively. The predicted dominant SOA component is from irreversible uptake of isoprene epoxydiol, which accounts for an episode-average of $38 \%$ (hourly contribution ranges from 24 to $60 \%$ ) of total SOA concentration. Semi-volatile SOA (12\%, 8-20\%), accretion products $(9 \%, 6-13 \%)$, and SOA from irreversible uptake of glyoxal (13\%, 8-20\%) and methylglyoxal $(27 \%, 15-35 \%)$ are abundant as well.

\subsection{Predicted SOA composition and properties}

\subsubsection{Concentrations of semi-volatile SOA and SOA from surface uptake}

Fig. 3 shows predicted regional concentration distributions of SOA and its components near the surface. Episode-averaged concentrations of total SOA are approximately $2-12 \mu \mathrm{g} \mathrm{m} \mathrm{m}^{-3}$ (Fig. 3(a)). Relatively high SOA concentrations in the range of $6-12 \mu \mathrm{g} \mathrm{m}^{-3}$ were predicted for southeastern Texas, Louisiana, Mississippi, and southwestern Alabama; interactions between the large amounts of biogenic VOCs emitted in those regions with anthropogenic $\mathrm{NO}_{x}$ were responsible. Fig. 3(b) shows that semi-volatile SOA component accounts for approximately $15-20 \%$ of the total SOA concentration, with a maximum concentration of approximately $1.8 \mu \mathrm{g} \mathrm{m} \mathrm{m}^{-3}$ in southwestern Alabama. The Houston area in 

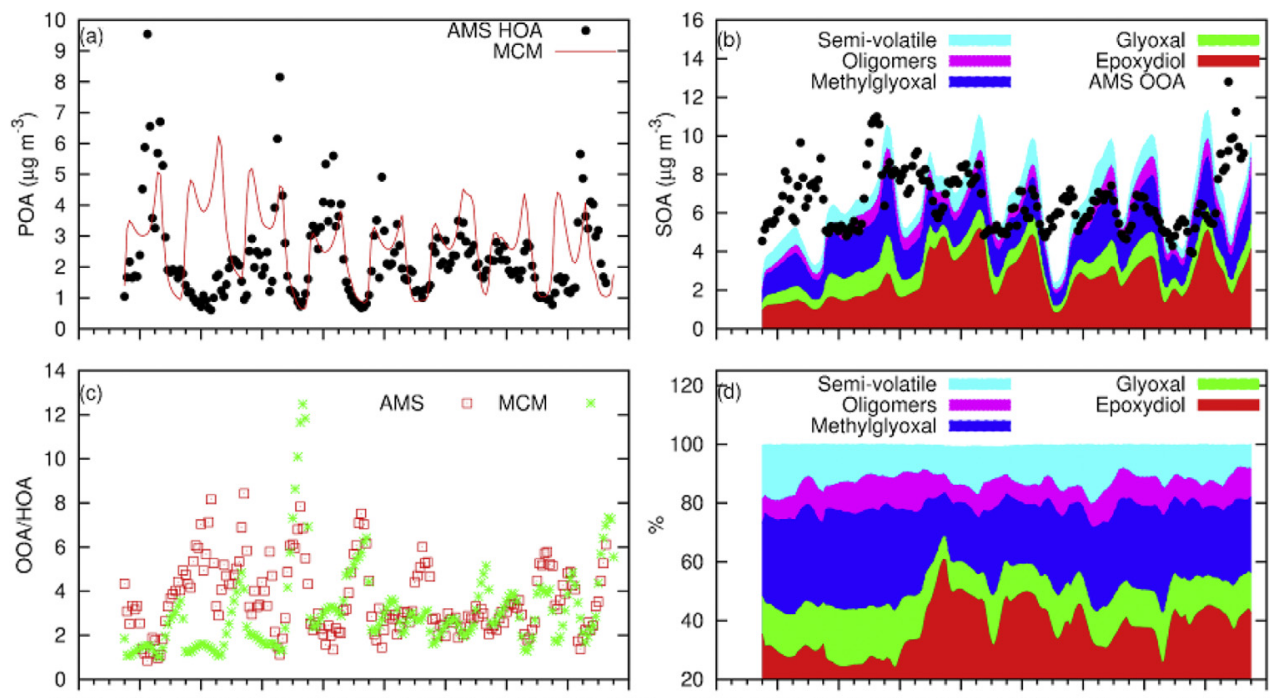

08/30 08/31 09/01 09/02 09/03 09/04 09/05 09/06 09/07 09/08 Time (CST)

08/30 08/31 09/01 09/02 09/03 09/04 09/05 09/06 09/07 09/08 Time (CST)

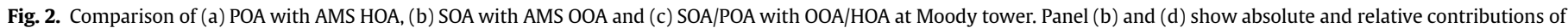
each SOA component to total SOA. (CST: Central Standard Time).
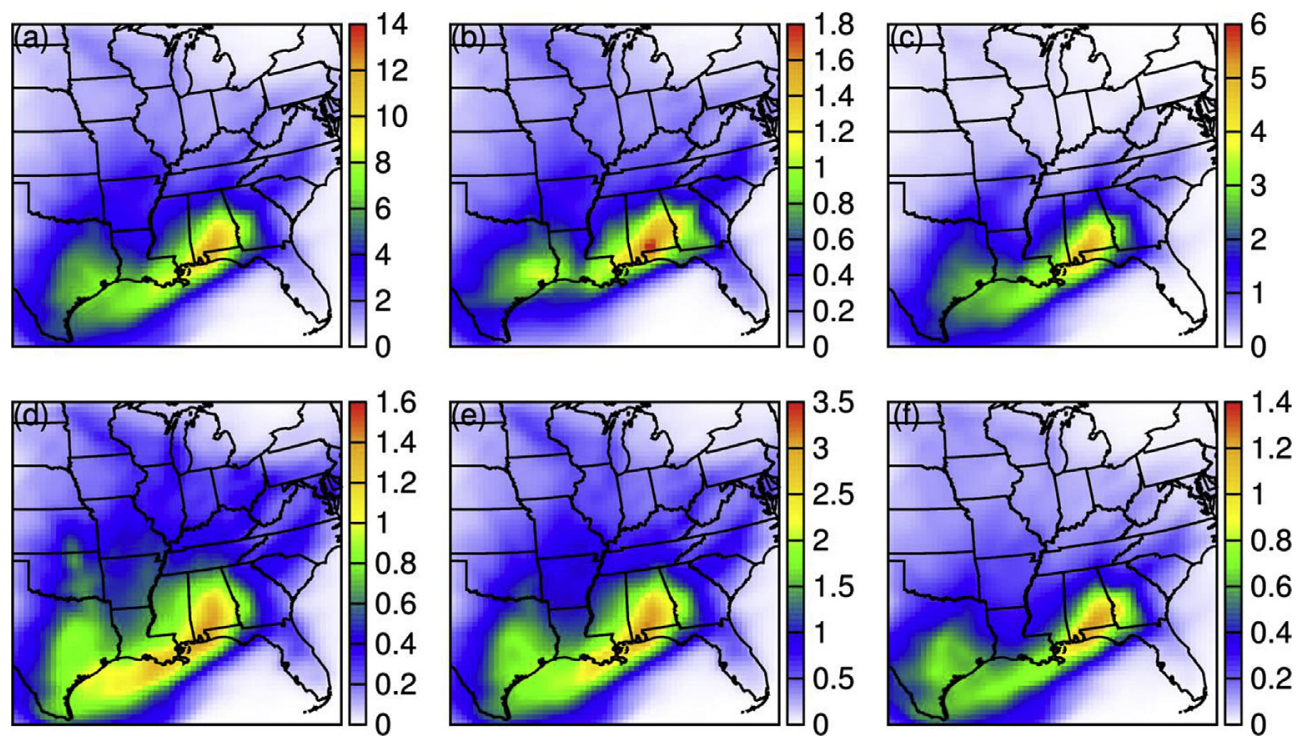

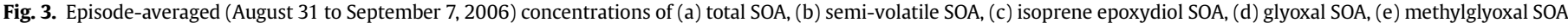
and (f) accretion products in the eastern US. Units are $\mu \mathrm{g} \mathrm{m}^{-3}$. Note that the scales for different panels are different to better illustrate the regional distributions.

southeastern Texas shows relatively high semi-volatile SOA concentrations of $1 \mathrm{\mu g} \mathrm{m}^{-3}$. Examination of the semi-volatile SOA composition output indicates that $\beta$-caryophyllene was major predicted precursor, in agreement with Zhang and Ying (2011).

Isoprene epoxydiol formed under low- $\mathrm{NO}_{x}$ conditions was predicted to produce significant amount of SOA in the southeastern US (Fig. 3(c)). The maximum concentration of the SOA predicted to form from this compound was approximately $5 \mu \mathrm{g} \mathrm{m} \mathrm{m}^{-3}$, about $40-45 \%$ of the total SOA in that region. A large contribution of epoxydiol to SOA has been hypothesized recently ( $33 \pm 10 \%$ of total SOA at Atlanta, Georgia) using positive matrix factorization of AMS data (Budisulistiorini et al. (2013)). In our study, the predicted episode-averaged concentration of SOA formed from epoxydiol at Atlanta, Georgia was found to be $\sim 1.1 \mu \mathrm{g} \mathrm{m}^{-3}$, or $31 \%$ of the total SOA. The average particle acidity during the simulation period and the corresponding uptake coefficient $\gamma_{\text {IEPOx }}$ are shown in Fig. 4. The predicted values of $\gamma_{\text {IEPOX }}$ reached $1.8 \times 10^{-3}$ in areas with high
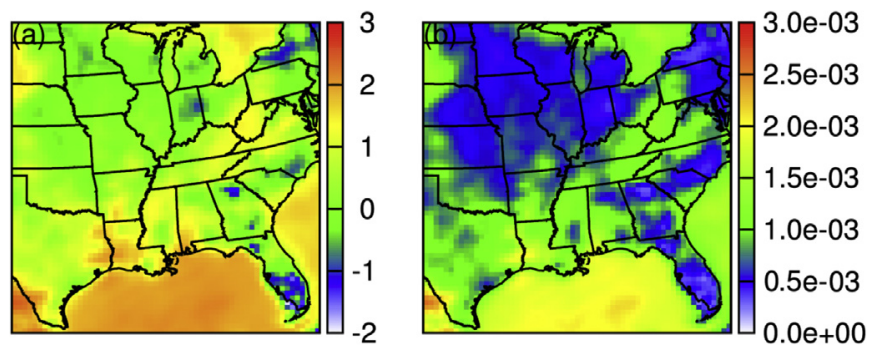

Fig. 4. Episode-averaged (a) $\ln \left(m_{\mathrm{H}^{+}}\right)\left(\mathrm{mol} \mathrm{kg} \mathrm{kg}^{-1}\right)$ of particles predicted by ISORROPIA and (b) uptake coefficient of epoxydiol ( $\left.\gamma_{\text {isopepox }}\right)$. 
predicted acidity. In most areas, $\gamma_{\text {IEPOX }}$ was predicted to be below $1 \times 10^{-3}$. These predictions agree with those of Pye et al. (2013).

Reactive uptake of glyoxal and methylglyoxal were predicted to be very important pathways capable of causing high SOA loading (Fig. 3(d) and (e)). The maximum episode-averaged concentrations of the two SOA source apportioned components were found to be 1.4 and $3.0 \mu \mathrm{g} \mathrm{m}^{-3}$, respectively. Their combined contribution accounted for $\sim 35 \%$ of the total predicted SOA in the southeastern US, and $70 \%$ in the northern US. These results are in general agreement with conclusions of the global SOA modeling study of Lin et al. (2012a) which concluded that in North America the highest annual SOA concentration occur in the southeastern US, and that isoprene epoxydiol, glyoxal and methylglyoxal SOA are major contributors to total SOA mass. Glyoxal and methylglyoxal SOA show slightly broader spatial distribution, extending towards north part of the domain. Fig. 3(f) shows that approximately $10 \%$ of the total SOA was composed of accretion products, with concentration ranges from 0.2 to $1.2 \mu \mathrm{g} \mathrm{m}^{-3}$. The spatial distribution of accretion products was similar to that of semi-volatile SOA components.

Vertical distributions of averaged predicted zonal concentrations of SOA are shown in Fig. 5. For total SOA, the predicted concentration was highest at around $30^{\circ} \mathrm{N}$. Total SOA concentration at $30^{\circ} \mathrm{N}$ had a maximum concentration of approximately $4.7 \mu \mathrm{g} \mathrm{m}^{-3}$ near the surface. The concentrations decreased slowly upwards until $2100 \mathrm{~m}$, followed by a rapid decrease above that. For semivolatile SOA (Fig. 5(b)), the highest concentration occurred at the surface. Dilution and enhanced photo-degradation of peroxides were predicted to reduce the SOA concentrations by more than $30 \%$ above $1100 \mathrm{~m}$. SOA formed from isoprene epoxydiol had the highest contribution to total SOA concentrations compared to other components at all levels (Fig. 5(c)). It had a relative uniform vertical distribution, keeping approximately $70 \%$ of the surface concentration at $\sim 1400 \mathrm{~m}$. This distribution pattern was caused by the nonvolatility of products formed from isoprene epoxydiol uptake; these species do not evaporate as they are transported upwards. Glyoxal and methylglyoxal SOA and accretion products are nonvolatile and there was no significant reduction in their concentrations observed within $500 \mathrm{~m}$. However, due to photolysis reactions of glyoxal and methylglyoxal, a decrease of concentration at higher altitude above $520 \mathrm{~m}$ was predicted. A wider latitudinal distribution for glyoxal and methylglyoxal is more apparent here, which is consistent with Fig. 3(d) and (e).

\subsubsection{Major semi-volatile SOA species}

Fig. 6 shows the regional distribution of episode-averaged column total concentration of major semi-volatile SOA species. Column total was used to reflect better meteorological impacts on SOA away from enhanced surface concentrations. The most abundant species was $\mathrm{C} 132 \mathrm{OOH}\left(\mathrm{C}_{13} \mathrm{H}_{22} \mathrm{O}_{5}\right.$, see Table $\mathrm{S} 2$ for the structures of major semi-volatile SOA species; structures of MCM species can also be obtained directly from the search page of the MCM website http://mcm.leeds.ac.uk/MCM/search.htt), which is a second generation product from $\beta$-caryophyllene ozonolysis. The highest column total concentration of this compound was approximately $0.2 \mu \mathrm{g} \mathrm{m}^{-2}$ and occurred downwind of Houston and Atlanta. The second, third, fourth and sixth highest semi-volatile SOA components BCSOZOOH $\left(\mathrm{C}_{15} \mathrm{H}_{26} \mathrm{O}_{6}\right.$, Fig. 6(b)), C1330OH $\left(\mathrm{C}_{13} \mathrm{H}_{22} \mathrm{O}_{6}\right.$, Fig. 6(c)), INDOOH $\left(\mathrm{C}_{5} \mathrm{H}_{11} \mathrm{NO}_{7}\right.$, Fig. 6(d)) and C133CO $\left(\mathrm{C}_{13} \mathrm{H}_{20} \mathrm{O}_{5}\right.$, Fig. 6(f)) also peaked in areas downwind of major cities. BCSO$\mathrm{ZOOH}, \mathrm{C} 133 \mathrm{OOH}$ and $\mathrm{C} 133 \mathrm{CO}$ are ozone and $\mathrm{OH}$ oxidation products of $\beta$-caryophyllene under low- $\mathrm{NO}_{x}$ conditions, and INDOOH is a second generation $\mathrm{OH}$ oxidation product of isoprene. The direct precursor of INDOOH in MCM is ISOPDNO3, which is one of the four isomeric first generation hydroxynitrates formed from isoprene reaction with $\mathrm{OH}$ under high- $\mathrm{NO}_{x}$ conditions. ISOPDNO3 subsequently forms INDOOH due to reaction with $\mathrm{OH}$ and the other hydroxynitrates undergo similar reactions to form isomers of INDOOH. The other abundant species was MNNCATCOOH $\left(\mathrm{C}_{7} \mathrm{H}_{8} \mathrm{~N}_{2} \mathrm{O}_{11}\right.$, Fig. $\left.6(\mathrm{e})\right)$, which is a third or higher generation product of toluene reaction with $\mathrm{OH}$. MNNCATCOOH showed a very different spatial distribution compared to the biogenic SOA products, with a much broader distribution that is very similar to that of sulfate demonstrated by Li et al. (2013). This suggests that toluene SOA was formed with sulfate in plumes originating from urban and industrial regions and could be transported over long distances.

Major semi-volatile products during the day were different from those at night because of changes in emitted VOCs and oxidation pathways. Fig. 7 shows episode-averaged major species contributions to daytime and nighttime semi-volatile SOA based on the total

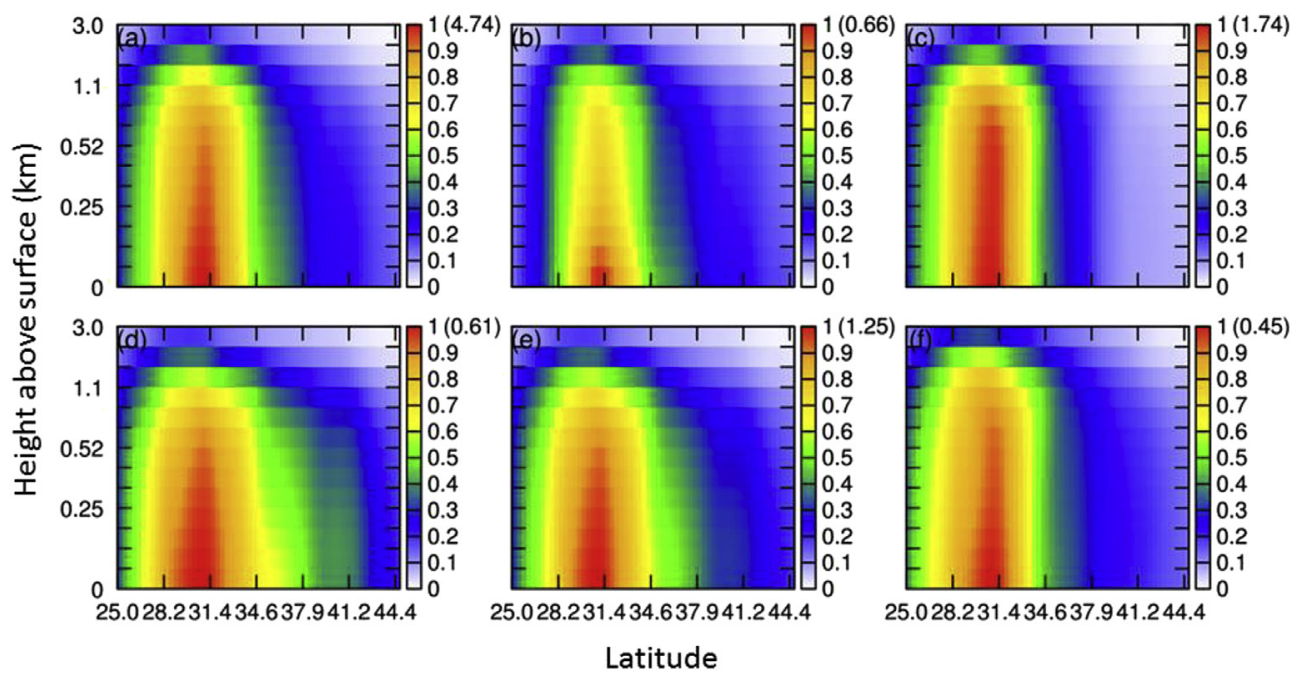

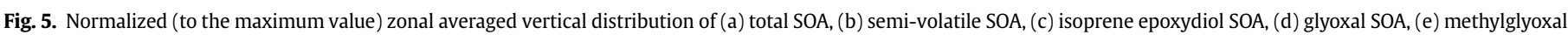

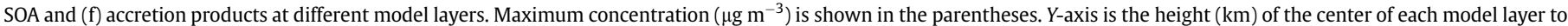

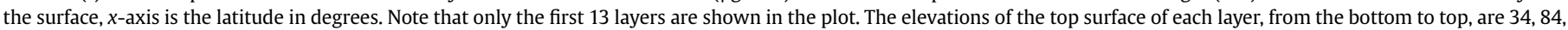
$170,256,342,429,518,606,786,1062,1346,2092$ and $3009 \mathrm{~m}$ above surface. 

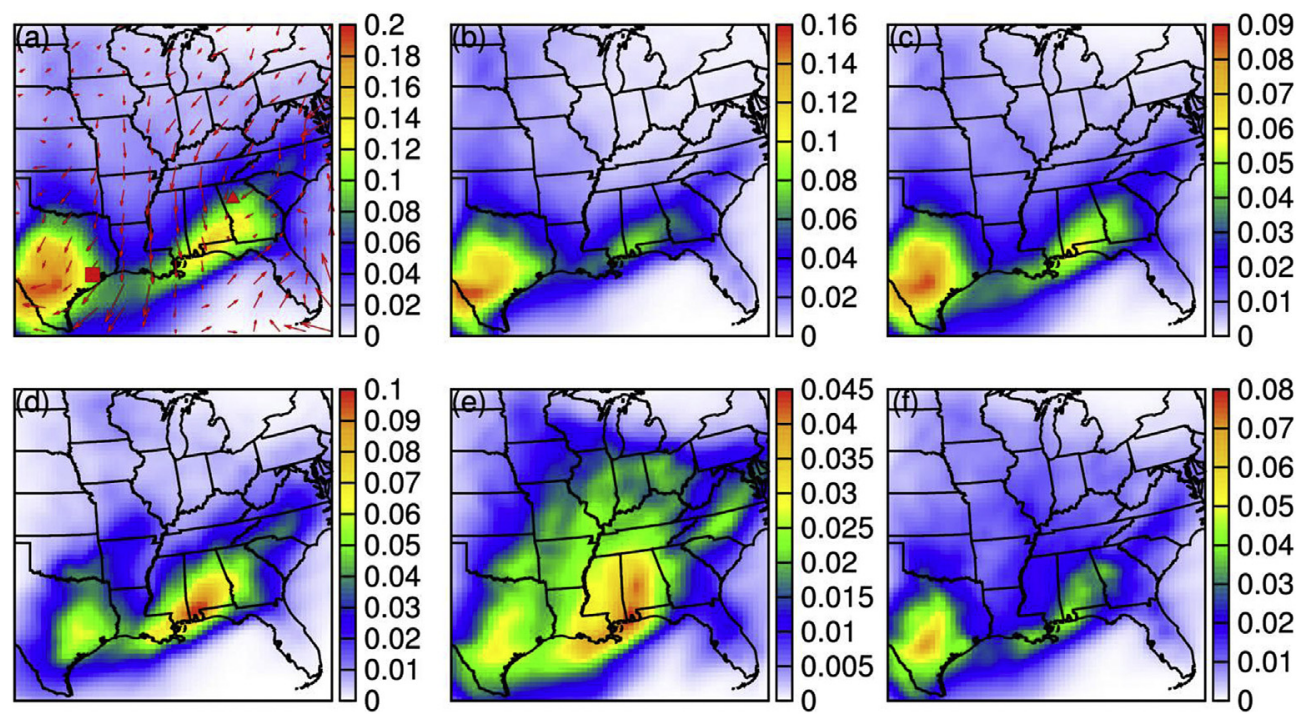

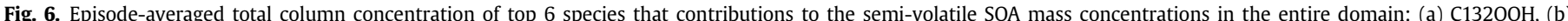

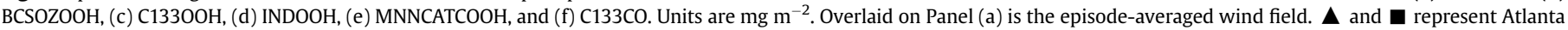
and Houston, respectively.

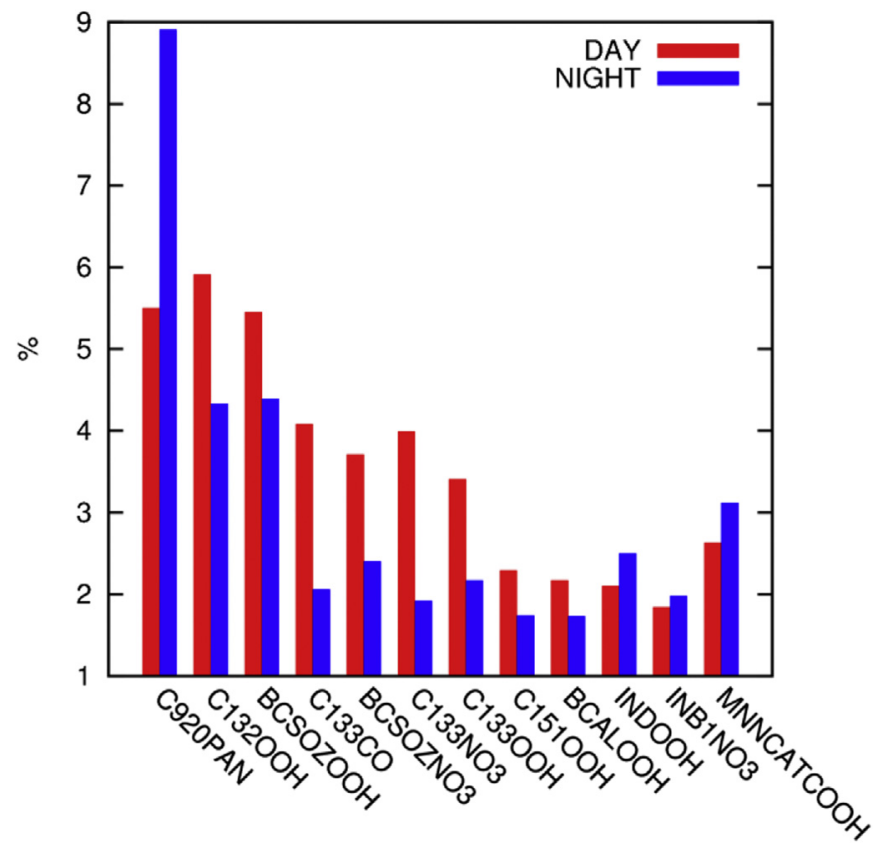

Fig. 7. Episode-averaged percentage contributions of top species to semi-volatile SOA during day time (6:00-20:00 CST) and night time (21:00-5:00 CST) in the entire domain.

surface concentrations in the domain. The difference in the major species based on surface concentrations and column total concentrations is due to the difference in the vertical distribution of different SOA components, as shown in Fig. 5, as well as in Figs. S5 and S6. The most abundant SOA species C920PAN was a product of $\mathrm{NO}_{2}$ and $\mathrm{C} 920 \mathrm{CO} 3$, which is a complex $\mathrm{C} 10$ acyl peroxy radical generated from $\alpha$-pinene ozonolysis. It had higher contribution at night due to lower temperature and decreased levels of $\mathrm{OH}$ and $\mathrm{NO}_{2}$ that reduce the net loss of $\mathrm{C} 920 \mathrm{CO} 3$. C132OOH, C133CO, C133NO3, $\mathrm{BCSOZOOH}, \mathrm{BCSOZNO3}, \mathrm{C} 13300 \mathrm{H}, \mathrm{C} 1510 \mathrm{OH}$, and BCALOOH had higher concentrations during the day; all are products of $\beta$-caryophyllene oxidation. The significant day vs. night differences of these species are due mainly to the strong diurnal variation of $\beta$ caryophyllene emission (Fig. S7(b)). Concentrations of other species (INDOOH, INB1NO3, and MNNCATCOOH) were slightly higher at night.

\subsection{3. $\mathrm{O} / \mathrm{C}, \mathrm{H} / \mathrm{C}, \mathrm{H} / \mathrm{C}$ and $\mathrm{OM} / \mathrm{OC}$ of $\mathrm{SOA}$}

The explicit representation of SOA components can be used to calculate some overall properties of SOA. Episode-averaged $\mathrm{O} / \mathrm{C}, \mathrm{H} /$ $\mathrm{C}, \mathrm{N} / \mathrm{C}$ and $\mathrm{OM} / \mathrm{OC}$ values for semi-volatile SOA are shown in Fig. 8(a-d). Assuming (1) the SOA from glyoxal, methylglyoxal and isoprene epoxydiol have molecular composition of $\mathrm{C}_{2} \mathrm{H}_{2} \mathrm{O}_{2}, \mathrm{C}_{3} \mathrm{H}_{4} \mathrm{O}_{2}$, and $\mathrm{C}_{5} \mathrm{H}_{10} \mathrm{O}_{3}$, respectively, and (2) the accretion products from semi-volatile SOA have the same molecular composition as the average semi-volatile SOA, these properties were also estimated for the predicted total SOA, as shown in Fig. 8(e-g). O/C for semivolatile SOA ranged from 0.4 to 0.9 in most areas, and higher $\mathrm{O} / \mathrm{C}$ values occurred in the northeastern US. When other SOA components were considered, the predicted $\mathrm{O} / \mathrm{C}$ ratio ranged from 0.6 to 0.8 . $\mathrm{H} / \mathrm{C}$ for semi-volatile SOA ranged from 1.2 to 1.8 , and decreased slightly in most areas when other SOA components were considered. N/C for semi-volatile SOA ranges from 0.02 to 0.16 over the entire domain and most areas had $\mathrm{N} / \mathrm{C}$ ratio higher than 0.1 . This is much higher than reported N/C for OOA in the literature (Setyan et al., 2012). However, when other SOA components were considered, the $\mathrm{N} / \mathrm{C}$ ratio ranged from 0.01 to 0.03 , in better agreement with reported N/C for OOA from AMS measurements. The OM/OC ratio for semi-volatile SOA ranged from 1.8 to 2.6 in most areas. The upper limits are higher than most values of the OM/OC ratio reported in the literature (Aiken et al., 2009; Setyan et al., 2012; Zhang et al., 2005). OM/OC decreased to 1.9-2.2 when other SOA components were considered. $\mathrm{H} / \mathrm{C}, \mathrm{O} / \mathrm{C}, \mathrm{N} / \mathrm{C}$ and $\mathrm{OM} / \mathrm{OC}$ values at the Moody Tower for semi-volatile SOA/overall SOA were 1.65/1.63, $0.62 / 0.67,0.061 / 0.013$ and $2.03 / 2.04$, respectively. These properties of overall SOA are in good agreement with organic aerosol properties in Mexico City measured by AMS $(\mathrm{H} / \mathrm{C}=1.47, \mathrm{O} / \mathrm{C}=0.60, \mathrm{~N} /$ $\mathrm{C}=0.01$ and $\mathrm{OM} / \mathrm{OC}=1.95$ ) (Aiken et al., 2009). Observed $\mathrm{O} / \mathrm{C}$ for $\mathrm{POA}+\mathrm{SOA}$ at the Moody Tower, assuming $\mathrm{O} / \mathrm{C}=0.16$ for POA (Aiken et al., 2009), also generally agree with observed $\mathrm{O} / \mathrm{C}$, as shown in Fig. 9. Over-prediction of $\mathrm{O} / \mathrm{C}$ for sample 4 and 5 (for September 2) is likely due to simultaneous under-prediction of POA 


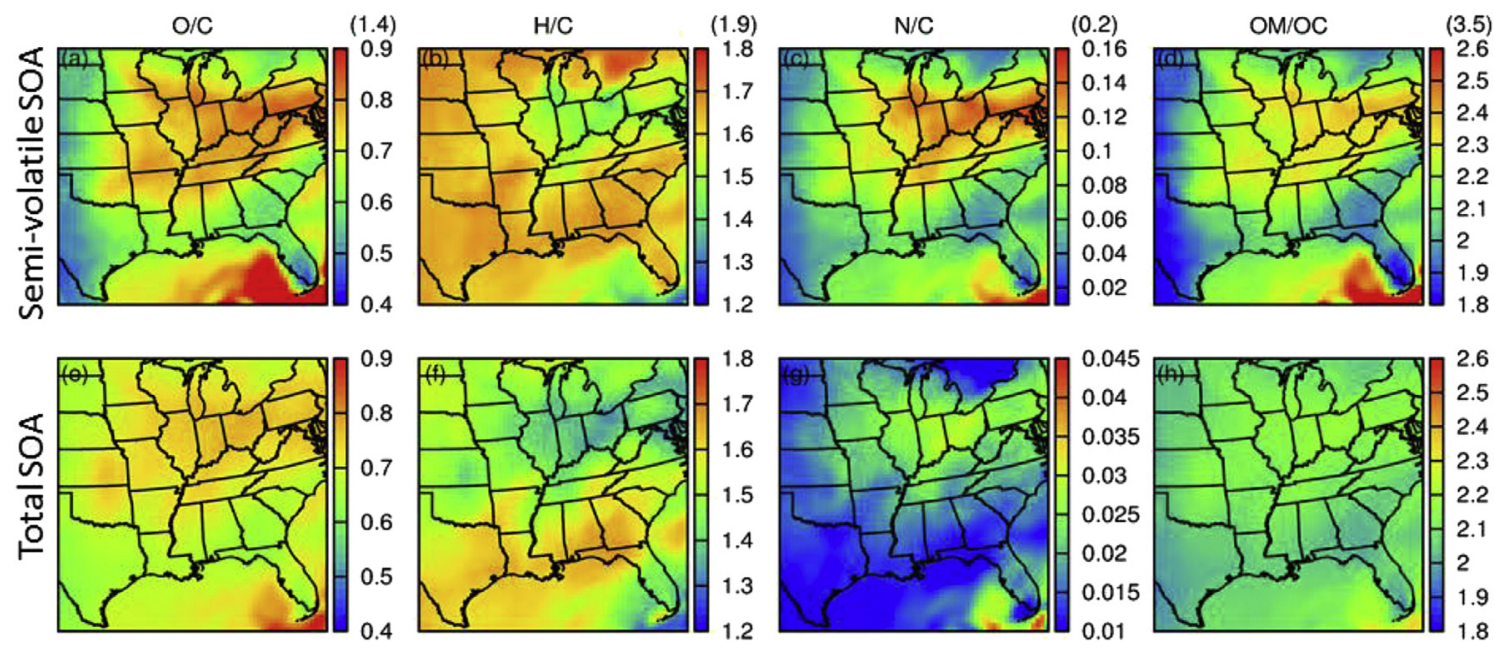

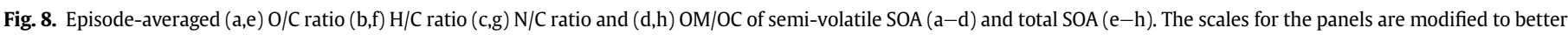
illustrate spatial distribution. The maximum values are shown in parentheses.

and over-predictions of SOA on that day (see Fig. 2). Zonal averaged vertical distribution of $\mathrm{O} / \mathrm{C}, \mathrm{H} / \mathrm{C}$ and $\mathrm{N} / \mathrm{C}$ of SOA due to major anthropogenic and biogenic emission precursors are shown in Figs. S4 and S5, respectively.

\subsection{Sensitivity of model predictions to selected parameters}

\subsubsection{Sensitivity to saturation vapor pressure}

Saturation vapor pressure is a key factor that governs the partitioning of SVOC and therefore SOA formation. However, many of the nitrates and peroxides from VOC oxidation are complex in structure, leading to large uncertainties in the estimated vapor pressure (Compernolle et al., 2010). Previous SOA modeling studies using MCM reported that saturation vapor pressures needed to be reduced by a factor of $5-500$ to better reproduce the observed SOA formation in environmental chambers and in the field (Jenkin, 2004; Johnson et al., 2004, 2006b, 2005). However, the sensitivity of $p_{L}^{o}$ estimation in 3D Eulerian models has not been evaluated. The EPI-predicted $p_{L}^{0}$ values used in this study were uniformly reduced by a factor of 100 to study the sensitivity of predicted semi-volatile SOA concentrations to this important parameter. As shown in Fig. 10, decreasing the saturation vapor pressure leads to increase of episode-averaged total SOA by up to $18 \mu \mathrm{g} \mathrm{m}^{-3}$ ( 2.3 times higher). Approximately $2 / 3\left(12 \mu \mathrm{g} \mathrm{m}^{-3}\right)$ of the increase is due to semivolatile products ( $~ 8$ times higher). Accretion product concentrations also are increased significantly by up to $7 \mu \mathrm{g} \mathrm{m}^{-3}$ ( $\sim 6$ times higher). Changes to other SOA components are rather small, as expected. SOA from epoxydiol shows only a small increase of up to $0.3 \mu \mathrm{g} \mathrm{m}^{-3}$, possibly due to increase in aerosol surface area or increased SOA partitioning of $\mathrm{NO}_{x}$ reservoir species, resulting a decrease in the $\mathrm{NO}_{x}$ concentration. Glyoxal and methylglyoxal SOA show a small decrease of $\sim 0.2 \mu \mathrm{g} \mathrm{m}^{-3}$ in the high concentration area, due to decrease in their precursor concentrations. Major semivolatile SOA species also have changed significantly. In the base case, $\beta$-caryophyllene is the primary semi-volatile SOA precursor. After scaling SVP for all the SVOCs, oxidation products generated from $\alpha$ - and $\beta$-pinene become the dominant components of semivolatile SOA at ground level, based on the total concentration in the domain. The increasing importance of the pinene products presumably reflects that they are formed in higher yield than the $\beta$ caryophyllene products but were previously largely present in the gas phase. The $\beta$-caryophyllene products were already largely in the SOA phase so their SOA concentration is less sensitive to

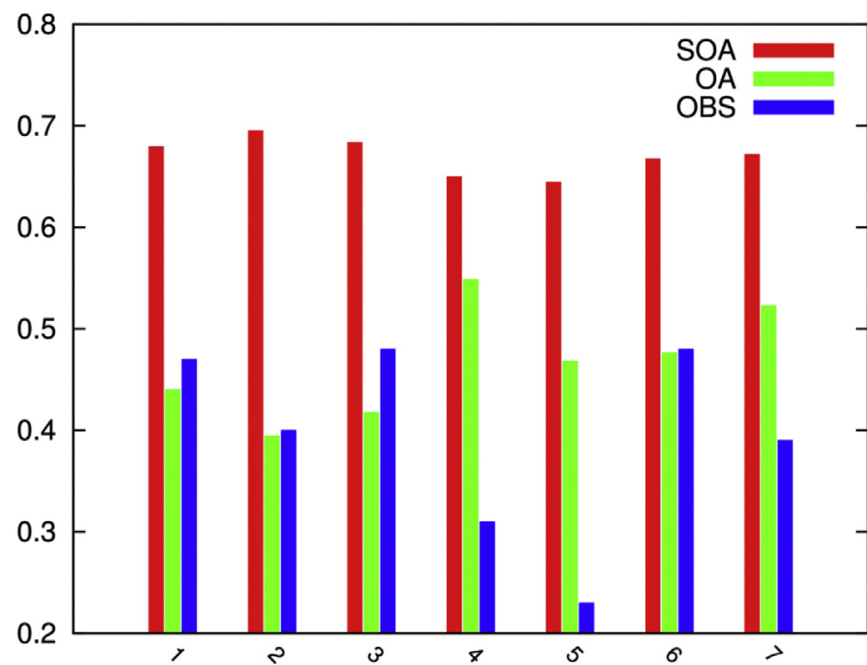

Fig. 9. Predicted $\mathrm{O} / \mathrm{C}$ for $\mathrm{SOA}$ and overall $\mathrm{OA}$ and observed $\mathrm{O} / \mathrm{C}$ for $\mathrm{OA}(\mathrm{OBS})$ at the Moody Tower. Starting and ending time for samples 1 to 7 are (all CST): (1) 0900-1930 Aug. 31; (2) 2000 Aug. 31-0830 Sep. 1; (3) 2000 Sep. 1-0830 Sep. 2; (4) 0900 Sep. 2-1815 Sep. 3; (5) 1930 Sep. 2-0830 Sep. 3; (6) 0840-1900 Sep. 5; and (7) 0840-1920 Sep. 7. The predictions are based on hourly predictions that include the sample starting and ending times. The observations (unpublished) were used to calculate the reported $\mathrm{O} / \mathrm{C}$ in Cleveland et al. (2012).

changes in vapor pressure. This simulation suggests that predicted SOA concentrations are sensitive to the predicted SVP, especially if the predicted SVP values have clear biases in the same direction.

\subsubsection{Sensitivity to activity coefficient}

To investigate any non-ideality effect on SVOCs partitioning and formation of semi-volatile SOA components, a sensitivity simulation (the UNIFAC case) was conducted by enabling the calculation of activity coefficients using the UNIFAC method described in Section 2.2. When activity coefficients were calculated, predicted total SOA concentration decreases slightly by up to $0.3 \mu \mathrm{g} \mathrm{m} \mathrm{m}^{-3}$ in areas where SOA concentrations are the highest. Throughout the domain, the UNIFAC case predicts a decrease of SOA by $2-4 \%$. The biggest impact is on the predicted semi-volatile SOA component, with $5-15 \%$ of decrease in most parts of the domain. There is also a similar amount of decrease in the accretion product concentrations 

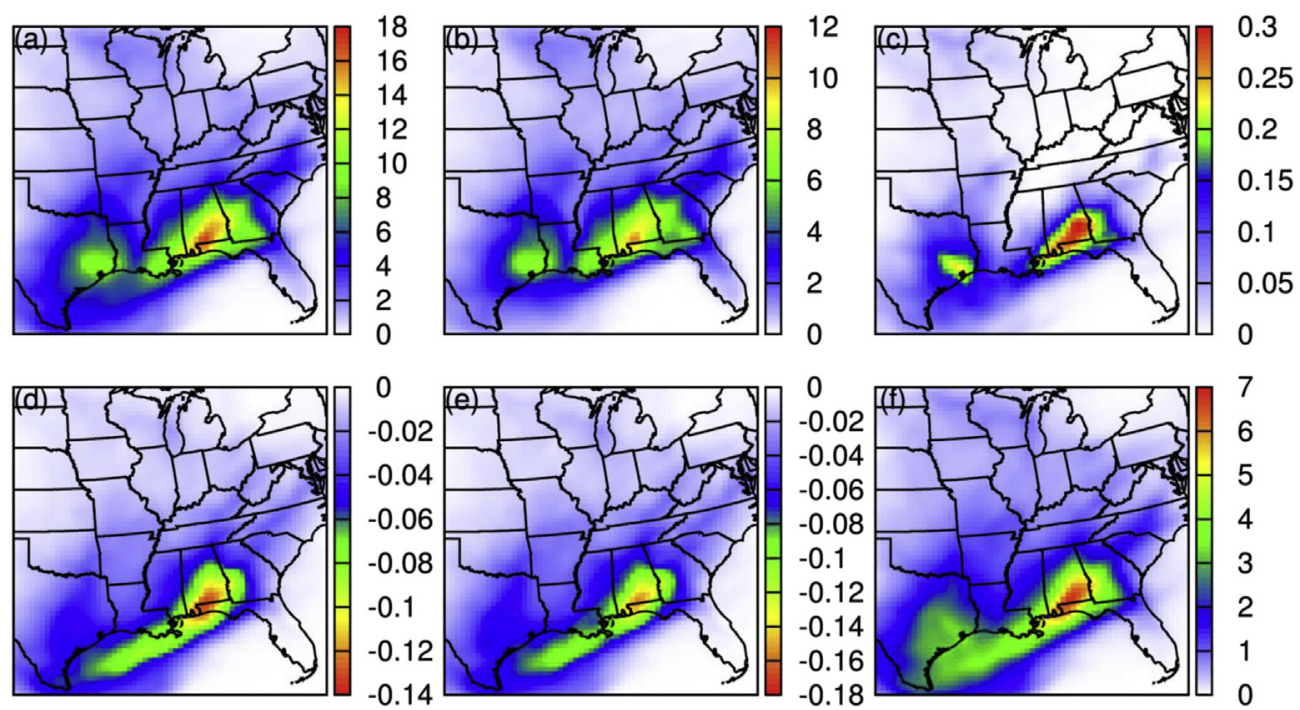

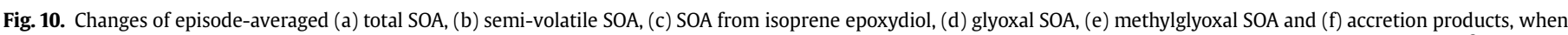
SVP of each semi-volatile product is reduced by a factor of 100 . Positive numbers mean increase in the predicted concentrations from the base case. Units are $\mu \mathrm{g} \mathrm{m}^{-3}$.

of $5-10 \%$ in the domain. Impacts on glyoxal and methylglyoxal SOA and SOA from epoxydiol are negligible because the activity coefficients for their SOA products are fixed at unity in all simulations. While the relatively insensitive of the predicted SOA to the nonideality of the organic mixture is consistent with previous studies (Bowman and Melton, 2004; Compernolle et al., 2009), results from this simple sensitivity simulation may not be general; and can be very different if separation of organic phases and partitioning of water molecules to the organic phases were considered.

\section{Conclusions}

CMAQ-MCM-SOA with equilibrium partitioning of explicit semivolatile products and additional pathways of SOA formation due to reactive surface uptake of isoprene epoxydiol, glyoxal and methylglyoxal were applied to simulate SOA formation in the eastern US during a two-week episode from August 28 to September 7, 2006. Predicted POA and SOA concentrations and diurnal variations generally agree with AMS measured HOA and OOA at an urban Houston site. In the southeastern US, highest episode-averaged surface SOA concentration is $\sim 12 \mu \mathrm{g} \mathrm{m}^{-3}$. Isoprene epoxydiol contribute most to the total SOA formation in this region. However, the significance of this process is significantly affected by the acidity of the particles. Glyoxal and methylglyoxal SOA account for more than $35 \%$ of total SOA. SOA components from oxidation of $\beta$ caryophyllene dominate the semi-volatile SOA but the predicted major semi-volatile SOA components and their concentrations are sensitive to the estimated vapor pressure. Considering the nonideal behavior of one single organic mixture (ignoring phase separation and water molecule partitioning) by applying the UNIFAC calculated activity coefficient leads to approximately $10 \%$ change in the predicted semi-volatile SOA.

\section{Acknowledgments}

This project has been funded with funds from the State of Texas as part of the program of the Texas Air Research Center (Project Number 079ATM0099A, 078ATM2080A and 312ATM0126A). Support was also provided by the Electric Power Research Institute. The contents do not necessarily reflect the views and policies of the sponsors, nor does the mention of trade names or commercial projects constitute endorsement or recommendation for use. The authors would like to acknowledge the Texas A\&M Supercomputing Facility (http://sc.tamu.edu) and the Texas Advanced Computing Center (TACC) at The University of Texas at Austin (http://www.tacc.utexas.edu) for providing computing resources useful in conducting the research reported in this paper. The authors would also like to thank the two anonymous reviewers for their valuable comments and suggestions.

\section{Appendix A. Supplementary data}

Supplementary data related to this article can be found at http:// dx.doi.org/10.1016/j.atmosenv.2014.11.054.

\section{References}

Aiken, A.C., Salcedo, D., Cubison, M.J., Huffman, J.A., DeCarlo, P.F., Ulbrich, I.M Docherty, K.S., Sueper, D., Kimmel, J.R., Worsnop, D.R., Trimborn, A Northway, M., Stone, E.A., Schauer, J.J., Volkamer, R.M., Fortner, E., de Foy, B., Wang, J., Laskin, A., Shutthanandan, V., Zheng, J., Zhang, R., Gaffney, J. Marley, N.A., Paredes-Miranda, G., Arnott, W.P., Molina, L.T., Sosa, G. Jimenez, J.L., 2009. Mexico city aerosol analysis during MILAGRO using high resolution aerosol mass spectrometry at the urban supersite (T0) - part 1: fine particle composition and organic source apportionment. Atmos. Chem. Phys. 9 6633-6653.

Bloss, C., Wagner, V., Jenkin, M.E., Volkamer, R., Bloss, W.J., Lee, J.D., Heard, D.E. Wirtz, K., Martin-Reviejo, M., Rea, G., Wenger, J.C., Pilling, M.J., 2005. Development of a detailed chemical mechanism (MCMv3.1) for the atmospheric oxidation of aromatic hydrocarbons. Atmos. Chem. Phys. 5, 641-664.

Bowman, F.M., Melton, J.A., 2004. Effect of activity coefficient models on predictions of secondary organic aerosol partitioning. J. Aero. Sci. 35, 1415-1438.

Budisulistiorini, S.H., Canagaratna, M.R., Croteau, P.L., Marth, W.J., Baumann, K. Edgerton, E.S., Shaw, S.L., Knipping, E.M., Worsnop, D.R., Jayne, J.T., Gold, A., Surratt, J.D., 2013. Real-time continuous characterization of secondary organic aerosol derived from isoprene epoxydiols in downtown Atlanta, Georgia, using the aerodyne aerosol chemical speciation monitor. Environ. Sci. Technol. 47, 5686-5694.

Byun, D., Schere, K.L., 2006. Review of the governing equations, computational algorithms, and other components of the models-3 Community Multiscale Air Quality (CMAQ) modeling system. Appl. Mech. Rev. 59, 51-77.

Camredon, M., Aumont, B., Lee-Taylor, J., Madronich, S., 2007. The SOA/VOC/NO system: an explicit model of secondary organic aerosol formation. Atmos. Chem. Phys. 7, 5599-5610.

Carlton, A.G., Bhave, P.V., Napelenok, S.L., Edney, E.D., Sarwar, G., Pinder, R.W., Pouliot, G.A., Houyoux, M., 2010. Model representation of secondary organic aerosol in CMAQv4.7. Environ. Sci. Technol. 44, 8553-8560.

Chang, E.I., Pankow, J.F., 2010. Organic particulate matter formation at varying relative humidity using surrogate secondary and primary organic compounds 
with activity corrections in the condensed phase obtained using a method based on the Wilson equation. Atmos. Chem. Phys. 10, 5475-5490.

Clegg, S.L., Kleeman, M.J., Griffin, R.J., Seinfeld, J.H., 2008. Effects of uncertainties in the thermodynamic properties of aerosol components in an air quality model part 1: treatment of inorganic electrolytes and organic compounds in the condensed phase. Atmos. Chem. Phys. 8, 1057-1085.

Cleveland, M.J., Ziemba, L.D., Griffin, R.J., Dibb, J.E., Anderson, C.H., Lefer, B., Rappenglück, B., 2012. Characterization of urban aerosol using aerosol mass spectrometry and proton nuclear magnetic resonance spectroscopy. Atmos. Environ. 54, 511-518.

Compernolle, S., Ceulemans, K., Muller, J.F., 2009. Influence of non-ideality on condensation to aerosol. Atmos. Chem. Phys. 9, 1325-1337.

Compernolle, S., Ceulemans, K., Müller, J.F., 2010. Technical note: vapor pressure estimation methods applied to secondary organic aerosol constituents from $\alpha$ pinene oxidation: an intercomparison study. Atmos. Chem. Phys. 10, 6271-6282.

Ervens, B., Volkamer, R., 2010. Glyoxal processing by aerosol multiphase chemistry: towards a kinetic modeling framework of secondary organic aerosol formation in aqueous particles. Atmos. Chem. Phys. 10, 8219-8244.

Foley, K.M., Roselle, S.J., Appel, K.W., Bhave, P.V., Pleim, J.E., Otte, T.L., Mathur, R. Sarwar, G., Young, J.O., Gilliam, R.C., Nolte, C.G., Kelly, J.T. Gilliland, A.B. Bash, J.O., 2010. Incremental testing of the Community Multiscale Air Quality (CMAQ) modeling system version 4.7. Geosci. Model Dev. 3, 205-226.

Fredenslund, A., Jones, R.L., Prausnitz, J.M., 1975. Group-contribution estimation of activity-coefficients in nonideal liquid-mixtures. AIChE J. 21, 1086-1099.

Fu, T.M., Jacob, D.J., Wittrock, F., Burrows, J.P., Vrekoussis, M., Henze, D.K., 2008. Global budgets of atmospheric glyoxal and methylglyoxal, and implications for formation of secondary organic aerosols. J. Geophys. Res. Atmos. 113.

Griffin, R.J., Dabdub, D., Kleeman, M.J., Fraser, M.P., Cass, G.R., Seinfeld, J.H., 2002a. Secondary organic aerosol 3. Urban/regional scale model of size- and composition-resolved aerosols. J. Geophys. Res. 107, 4334.

Griffin, R.J., Dabdub, D., Seinfeld, J.H., 2002b. Secondary organic aerosol 1. Atmospheric chemical mechanism for production of molecular constituents. J. Geophys. Res. 107, 4332.

Heald, C.L., Jacob, D.J., Park, R.J., Russell, L.M., Huebert, B.J., Seinfeld, J.H., Liao, H., Weber, R.J., 2005. A large organic aerosol source in the free troposphere missing from current models. Geophys. Res. Lett. 32, L18809.

Jacobson, M.Z., 1998. Improvement of SMVGEAR II on vector and scalar machines through absolute error tolerance control. Atmos. Environ. 32, 791-796.

Jacobson, M.Z., 1999. Fundamentals of Atmospheric Modeling. Cambridge University Press, New York.

Jacobson, M.Z., Tabazadeh, A., Turco, R.P., 1996. Simulating equilibrium within aerosols and nonequilibrium between gases and aerosols. J. Geophys. Res. Atmos. 101, 9079-9091.

Jenkin, M.E., 2004. Modelling the formation and composition of secondary organic aerosol from alpha- and beta-pinene ozonolysis using MCM v3. Atmos. Chem. Phys. 4, 1741-1757.

Jenkin, M.E., Saunders, S.M., Pilling, M.J., 1997. The tropospheric degradation of volatile organic compounds: a protocol for mechanism development. Atmos. Environ. 31, 81-104.

Jenkin, M.E., Saunders, S.M., Wagner, V., Pilling, M.J., 2003. Protocol for the development of the master chemical mechanism, MCM v3 (Part B): tropospheric degradation of aromatic volatile organic compounds. Atmos. Chem. Phys. 3 , $181-193$.

Jenkin, M.E., Wyche, K.P., Evans, C.J., Carr, T., Monks, P.S., Alfarra, M.R., Barley, M.H., McFiggans, G.B., Young, J.C., Rickard, A.R., 2012. Development and chambe evaluation of the MCM v3.2 degradation scheme for $\beta$-caryophyllene. Atmos. Chem. Phys. 12, 5275-5308.

Johnson, D., Jenkin, M.E., Wirtz, K., Martin-Reviejo, M., 2004. Simulating the formation of secondary organic aerosol from the photooxidation of toluene. Environ. Chem. 1, 150-165.

Johnson, D., Jenkin, M.E., Wirtz, K., Martin-Reviejo, M., 2005. Simulating the formation of secondary organic aerosol from the photooxidation of aromatic hydrocarbons. Environ. Chem. 2, 35-48.

Johnson, D., Utembe, S.R., Jenkin, M.E., 2006a. Simulating the detailed chemica composition of secondary organic aerosol formed on a regional scale during the TORCH 2003 campaign in the southern UK. Atmos. Chem. Phys. 6, 419-431.

Johnson, D., Utembe, S.R., Jenkin, M.E., Derwent, R.G., Hayman, G.D., Alfarra, M.R., Coe, H., McFiggans, G., 2006b. Simulating regional scale secondary organic aerosol formation during the TORCH 2003 campaign in the southern UK. Atmos, Chem. Phys. 6, 403-418.

Kroll, J.H., Seinfeld, J.H., 2008. Chemistry of secondary organic aerosol: formation and evolution of low-volatility organics in the atmosphere. Atmos. Environ. 42, 3593-3624.

Lal, V., Khalizov, A.F., Lin, Y., Galvan, M.D., Connell, B.T., Zhang, R., 2012. Heterogeneous reactions of epoxides in acidic media. J. Phys. Chem. A 116, 6078-6090.

Lee-Taylor, J., Madronich, S., Aumont, B., Baker, A., Camredon, M., Hodzic, A. Tyndall, G.S., Apel, E., Zaveri, R.A., 2011. Explicit modeling of organic chemistry and secondary organic aerosol partitioning for Mexico city and its outflow plume. Atmos. Chem. Phys. 11, 13219-13241.

Li, J., Ying, Q., Yi, B., Yang, P., 2013. Role of stabilized criegee intermediates in the formation of atmospheric sulfate in eastern United States. Atmos. Environ. 79, $442-447$.

Liao, H., Henze, D.K., Seinfeld, J.H., Wu, S.L., Mickley, L.J., 2007. Biogenic secondary organic aerosol over the United States: comparison of climatological simulations with observations. J. Geophys. Res. Atmos. 112, D06201.
Lin, G., Penner, J.E., Sillman, S., Taraborrelli, D., Lelieveld, J., 2012a. Global modeling of SOA formation from dicarbonyls, epoxides, organic nitrates and peroxides. Atmos. Chem. Phys. 12, 4743-4774.

Lin, Y.H., Zhang, Z.F., Docherty, K.S., Zhang, H.F., Budisulistiorini, S.H., Rubitschun, C.L., Shaw, S.L., Knipping, E.M., Edgerton, E.S., Kleindienst, T.E., Gold, A., Surratt, J.D., 2012b. Isoprene epoxydiols as precursors to secondary organic aerosol formation: acid-catalyzed reactive uptake studies with authentic compounds. Environ. Sci. Technol. 46, 250-258.

Lyman, W.J., 1985. Environmental Exposure from Chemicals. CRC Press, Inc, Boca Raton, FL.

McFiggans, G., Topping, D.O., Barley, M.H., 2010. The sensitivity of secondary organic aerosol component partitioning to the predictions of component properties part 1: a systematic evaluation of some available estimation techniques. Atmos. Chem. Phys. 10, 10255-10272.

Na, K., Song, C., Cocker Iii, D.R., 2006. Formation of secondary organic aerosol from the reaction of styrene with ozone in the presence and absence of ammonia and water. Atmos. Environ. 40, 1889-1900.

Nenes, A., Pandis, S.N., Pilinis, C., 1998. ISORROPIA: a new thermodynamic equilibrium model for multiphase multicomponent inorganic aerosols. Aquat. Geochem. 4, 123-152.

Odum, J.R., Hoffmann, T., Bowman, F., Collins, D., Flagan, R.C., Seinfeld, J.H., 1996. Gas/particle partitioning and secondary organic aerosol yields. Environ. Sci. Technol. 30, 2580-2585.

Pandis, S.N., Wexler, A.S., Seinfeld, J.H., 1993. Secondary organic aerosol formation and transport .2. Predicting the ambient secondary organic aerosol-size distribution. Atmos. Environ. Part A Gen. Top. 27, 2403-2416.

Pankow, J.F., 1994. An absorption-model of the gas aerosol partitioning involved in the formation of secondary organic aerosol. Atmos. Environ. 28, 189-193.

Paulot, F., Crounse, J.D., Kjaergaard, H.G., Kürten, A., St. Clair, J.M., Seinfeld, J.H., Wennberg, P.O., 2009. Unexpected epoxide formation in the gas-phase photooxidation of isoprene. Science 325, 730-733.

Pun, B.K., Griffin, R.J., Seigneur, C., Seinfeld, J.H., 2002. Secondary organic aerosol 2. Thermodynamic model for gas/particle partitioning of molecular constituents. J. Geophys. Res. 107, 4333.

Pye, H.O.T., Pinder, R.W., Piletic, I.R., Xie, Y., Capps, S.L., Lin, Y.-H., Surratt, J.D., Zhang, Z., Gold, A., Luecken, D.J., Hutzell, W.T., Jaoui, M., Offenberg, J.H., Kleindienst, T.E., Lewandowski, M., Edney, E.O., 2013. Epoxide pathways improve model predictions of isoprene markers and reveal key role of acidity in aerosol formation. Environ. Sci. Technol. 47, 11056-11064.

Robinson, A.L., Donahue, N.M., Shrivastava, M.K., Weitkamp, E.A., Sage, A.M., Grieshop, A.P., Lane, T.E., Pierce, J.R., Pandis, S.N., 2007. Rethinking organic aerosols: semivolatile emissions and photochemical aging. Science 315, 1259-1262.

Saunders, S.M., Jenkin, M.E., Derwent, R.G., Pilling, M.J., 2003. Protocol for the development of the master chemical mechanism, MCM v3 (part A): tropospheric degradation of non-aromatic volatile organic compounds. Atmos. Chem. Phys. 3, 161-180.

Schnitzler, E.G., McDonald, K.M., 2012. Characterization of low-temperature vapour pressure estimates for secondary organic aerosol applications. Atmos. Environ. 56, 9-15.

Setyan, A., Zhang, Q. Merkel, M., Knighton, W.B., Sun, Y., Song, C., Shilling, J.E., Onasch, T.B., Herndon, S.C., Worsnop, D.R., Fast, J.D., Zaveri, R.A., Berg, L.K., Wiedensohler, A., Flowers, B.A., Dubey, M.K., Subramanian, R., 2012. Characterization of submicron particles influenced by mixed biogenic and anthropogenic emissions using high-resolution aerosol mass spectrometry: results from CARES. Atmos. Chem. Phys. 12, 8131-8156.

USEPA, 2009. Estimation Programs Interface Suite ${ }^{\mathrm{TM}}$ for Microsoft ${ }^{\mathbb{R}}$ Windows, fourth ed. United States Environmental Protection Agency, Washington, DC, USA.

Vaden, T.D., Imre, D., Beránek, J., Shrivastava, M., Zelenyuk, A., 2011. Evaporation kinetics and phase of laboratory and ambient secondary organic aerosol. Proc. Natl. Acad Sci. 108, 2190-2195.

Virtanen, A., Joutsensaari, J., Koop, T., Kannosto, J., Yli-Pirila, P., Leskinen, J., Makela, J.M., Holopainen, J.K., Poschl, U., Kulmala, M., Worsnop, D.R., Laaksonen, A., 2010. An amorphous solid state of biogenic secondary organic aerosol particles. Nature 467, 824-827.

Volkamer, R., Martini, F.S., Molina, L.T., Salcedo, D., Jimenez, J.L., Molina, M.J., 2007. A missing sink for gas-phase glyoxal in Mexico city: formation of secondary organic aerosol. Geophys. Res. Lett. 34.

Wang, T., Liu, Z., Wang, W., Ge, M., 2012. Uptake kinetics of three epoxides into sulfuric acid solution. Atmos. Environ. 56, 58-64.

Ying, Q., Cureño, I.V., Chen, G., Ali, S., Zhang, H., Malloy, M., Bravo, H.A., Sosa, R., 2014. Impacts of stabilized criegee Intermediates, surface uptake processes and higher aromatic secondary organic aerosol yields on predicted PM2.5 concentrations in the Mexico city metropolitan Zone. Atmos. Environ. 94, 438-447.

Ying, Q. Li, J., 2011. Implementation and initial application of the near-explicit master chemical mechanism in the 3D Community Multiscale Air Quality (CMAQ) model. Atmos. Environ. 45, 3244-3256.

Zhang, H., Ying, Q., 2011. Secondary organic aerosol formation and source apportionment in southeast Texas. Atmos. Environ. 45, 3217-3227.

Zhang, Q., Worsnop, D.R., Canagaratna, M.R., Jimenez, J.L., 2005. Hydrocarbon-like and oxygenated organic aerosols in Pittsburgh: insights into sources and processes of organic aerosols. Atmos. Chem. Phys. 5, 3289-3311. 